\title{
The Role of the Early Childhood Education in Building the Nation's Morality in the Era of Industrial Revolution 4.0
}

\author{
Warsono \\ \{warsono@unesa.ac.id\} \\ Universitas Negeri Surabaya, Indonesia
}

\begin{abstract}
This research is intended to explore the character taught at the preschool in Surabaya. This is based on the assumption that character education in early childhood is the basis for the nation's moral development. This study was qualitative with using an explorative approach. Data collection was done through in-depth interview techniques and field observations. Even though the character education curriculum for all preschool in Surabaya refers to the 2013 curriculum, the implementation is different since the vision and mission of each institution different, as well. Among the characters that are important to instill in the kindergarten are honesty, tolerance, independence, responsibility, discipline, creativity, courtesy, and social concern. These characters can be empirically exemplified and accustomed to in everyday life. The method of character education for children is habituation and example. Children often face a dilemma when there are differences in the characters in the family at school. Therefore, teachers and parents must be aware that they become models for children.
\end{abstract}

Keywords: Childhood education, nations morality, the industrial revolution

\section{Introduction}

Nowadays, the progress of a nation is no longer determined by natural resources but more determined by the quality of human resources. Facts have shown that developed countries, such as Japan, Singapore, and South Korea are nations that have nor natural resources, but they were being develop country because of having characters, such as honesty, discipline, responsibility, and tolerance for differences. A mental revolution which was proclaimed by President Joko Widodo has not shown significant results because corruption is still ongoing, and some are carried out by young people. A sting operation or Operasi Tangkap Tangan (OTT) carried out by Komisi Pemberantasan Korupsi (KPK) against the religious-based party elite ahead of the 2019 presidential and legislative elections showed that diversity could not prevent corruption.

Cheating could be defined as corruption in school. Cheating often did by students during the exam. Based on the massive fraud that occurred in SDN Gadel 2 Surabaya during the 
national examination on May, $10^{\text {th }}-12^{\text {th }} 2011$, the Mayor of Surabaya, Tri Rismaharini change her attitude and views on educations. Previously, she always emphasized the value of the national exam to indicate the success of schooling; then after the "Gadel 2" incident, she valued the importance of character rather than the value of the national exam. What is the use of smart children; if they do not have the right attitude, they will damage the nation. The right attitude which reflects good character cannot be formed automatically. It flows through a long educational process [1] starting from family, school, and community institutions. Each institution has the task of educating children to become an asset to develop the country. The government has included character education in the national education curriculum, starting from kindergarten to college.

According to Kohlberg, the most useful character education is when children are still young because children have not been contaminated by a bad thing. Therefore, the family is the first educational institution that has the most influence on children's moral development. However, in big cities and modern societies, family as the first educational institutions are increasingly fading its functionality. Parents are usually busy working and ignore their role as child educators. As a result, children lose their role models in their moral development. In this condition, preschools (PAUD) have a strategic role in children's moral education. Preschool is the other educational environment entered by children, after the family, so that they can replace or fill the vacant role of parents who are busy working. Children receive a structured education with a curriculum prepared by education experts. In Surabaya, almost all PAUD institutions are managed by the community who understand knowledge. Some are based on religion, while others are general, so they have a variety of visions and missions.

This research explores character education in PAUD institutions in Surabaya with various variants. The research questions are, (1) what characters are instilled in PAUD institutions in Surabaya city? (2) what are the obstacles faced in character education in PAUD? (3) are there differences in the character embedded in PAUD institutions that are religious-based with the public? The purpose of this research is to find out what characteristics are implanted in children; the method used and the difference in character priorities between religious-based and public PAUD. Character is an integral part of morality [2]. Characters have three interconnected moral components, namely moral knowing, moral feeling, and moral action [3]. Moral knowing includes moral awareness, knowledge of moral values, determination of perspectives, moral thinking, decision making, and personal knowledge. Moral feelings include conscience, self-esteem, empathy, good loving things, self-control, and humility. Moral actions include competence, desires, and habits.

The three components have causality, which influences each other. Knowledge will affect feelings, and feelings will affect actions and vice versa. Although human activities are not always determined by a single factor, at least between knowledge, attitudes, and actions, have a causal relationship. Human actions cannot be separated from rationality and desires. Human actions always refer to rationality whether namely rationality values, goals, pragmatics, or traditional [4]. Human activities are influenced by desire and trust, while trust is influenced by knowledge [5]. In the domain of moral knowing revealed by Lickona, there is an element of knowledge, awareness, and thinking, and decisions. There is a process in everyone, starting from knowing, understanding, living, believing, realizing, and doing. The knowledge that is supported by recognition and appreciation will guide one's beliefs. Confidence will guide consciousness, which, in turn, awareness will guide action [6].

In the domain of Lickona's moral feelings, there is also a conscience. By nature, conscience is a source of honesty, which is an essential component in character. No one can lie to God and himself. The result of dishonesty creates anxiety, anxiety, and fear. On the 
other hand, knowledge of the nature of themselves as social beings who cannot live alone, without the presence and assistance of others, should create awareness to develop tolerance towards differences. At least, then moral values must be cultivated respect for life and independence, honesty, responsibility, tolerance of differences, discipline, compassion, respect, justice, kindness, courage. Indeed, the source of morality is not only knowledge (thought), and conscience, but also religion. Allah reveals belief, the Almighty God as a guide for humans to lead to the path of goodness (Surat Al Baqara). In every religious teaching, some prohibitions and orders must be obeyed. Every religious person will believe the truth of the teachings of his religion. And based on these beliefs, they act and act.

Law No.20 of 2003 Article 1 paragraph 1 affirms that education is a conscious and planned effort to create a learning atmosphere and learning process so that students actively develop their potential to have divine spiritual power, self-control, intelligence, noble morality, and skills needed by him, society, nation, and country. Articles 5 to 6 state that every citizen (child) has the right to obtain education and teaching in the context of his personal development and his level of intelligence according to his interests and talents.

Article 1 point 14 affirms that Early Childhood Education (PAUD) is an effort to guide children from birth to 6 years of age through the provision of educational stimuli to help growth and physical and spiritual development so that children have more readiness to enter education goes on. As John Locke stated that every child born like a white paper or tabula rasa, in the sense that a newborn child does not have the knowledge and sin (according to religion), because they cannot lie. On the other hand, children's thinking ability has not developed well, because they have not been able to abstract. Until the age of six years, the cognitive development of children is still at the preoperational stage, which cannot yet think logically. Children always rely on their intuitive abilities.

Apart from a lack of knowledge, newborn children also cannot be said to have morals, because they have not been able to distinguish right from wrong. The moral is related to fundamental questions, namely right and wrong, justice, and fundamental human rights [7]. Norms and cultural values from the child's hometown strongly influence their morality in society [8]. Social values and norms are social facts that compel the behavior of community members. Cost is a good thing that is translated into the rule so that standards regulate human expression based on what is considered good and evil. These values and norms are passed down from generation to generation, so the character of a child cannot be separated from the conditions of his/her social environment [9]. Kohlberg also recognized the strength of social facts in character building. According to Kohlberg, children's moral development is in line with changes in the power of control from external to internal. Kohlberg divides children's moral development into three stages, namely pre-conventional, conventional, and postconventional [10].

In the pre-conventional stage, children's morale is still controlled by external forces in the form of punishment and gifts. In the current stage, children's confidence starts to refer to the standard norms that apply in the family environment, especially parents and the community. In the post-conventional stage, children's moral is no longer fully controlled by external forces. Children have begun to think and look for references to what is best for them. Only in adulthood, children's morals are in the conventional, and post-conventional. During the preconventional stage, children learn through imitating the behavior of others, especially those in the closest environment, such as parents or teachers. They also have not been able to determine the right and evil, except imitating the attitudes and behavior of others, especially parents [7]. Thus, children's morality in early childhood is still imitating the people in the surrounding environment. Therefore, the teacher is a role model for the character of the child. 
Teacher's words, attitudes, and behaviors are the character references of early childhood. What is said by people in the surrounding environment (parents and PAUD teachers) becomes a reference for children's morality, because language is intended for cognitive development?

Moreover, according to the ministry of education and culture, 18-character values must be instilled in students. These values are: religious, honest, tolerant, disciplined, hard work, creative, independent, democratic, curiosity, national spirit, love for the country, respect for achievement, friendly/good communication skill, peace-loving, fond of reading, caring for the environment, caring for the social, and responsibility. Of course, not all of these values are given to early childhood education. Each educational institution could develop its values based on religion and local culture, step-by-step according to the vision and mission of the institution.

\section{Research methods}

This study aims to explore character education in a preschool located in Surabaya, taking into account the characteristics of each educational institution. In Surabaya, there is a preschool that is managed by the Government or handled by the community. The preschool that led by the city could be based on a general (national) education or based on religious. According to data from the Surabaya City Education Office, educational institutions that handle preschool consist of four categories, which are Integrated PAUD with a total of 899 posts, Kindergartens with total 1,342 institutions, Playgroups with total 440 institutions and childcare with whole 46 centers. However, this research would only focus on kindergartens, so integrated PAUD, playgroups, and childcare were not the focus of research.

This study also tried to see the difference in character education in the two variants, religion-based training, and national-based education that managed by a community. TK Bina Tunas Bangsa in Lidah Wetan and TK Lab school Unesa Ketintang were selected to represent the national-based education TK AL Hikmah was chosen for Islamic-based knowledge, while Surabaya Gramer School (SGS) was chosen because all of the students are Cina. Data collection techniques were carried out through in-depth interviews and observation. Observations were made during the teaching and learning process, which focused on speech, attitudes, and behaviors related to the character shown by the teacher and child. In-depth interviews also the principal and teachers to understand what character or morals are being instilled in the child, the method that they were used, and obstacles encountered.

Data analysis was carried out using steps such as Miles and Habermas's theory, namely collecting data, displaying data, reducing data, and concluding. The collected data is selected, which are essential and which are not necessary, by focusing on the data to answer the problem statement, namely character education. Data collected, then simplified, and abstracted to capture the true meaning, in the form of character values that are taught, strategies, and methods used. The next step is presenting data (data display), in the way of a brief description or table or catalog of characters that are exemplified or educated to children. And the final step is to conclude by the formulation of the problem that has been determined. 


\section{Results and discussion}

Early Childhood Education (PAUD) in Surabaya refers to the 2013 curriculum, which consists of six aspects, namely: (1) religious and moral values; (2) motoric physics; (3) cognitive; (4) language; (5) social-emotional; and (6) art. Character education refers to 18character values set by the Minister of Education and Culture. The competence that must be achieved by the child in the curriculum is then translated into a Daily Learning Implementation Plan, as a guide for teachers in the teaching and learning process. Even so in its implementation, each PAUD can be different, influenced by the vision and mission of the institution and the teacher.

\section{TK Al-Hikmah}

Al-Hikmah Surabaya Kindergarten has a vision as an agent of community change towards a better life by the Qur'an and Sunnah. Therefore, TK Al-Hikmah offers a guarantee of moral quality that children recognize the spiritual values instilled through habituation, which includes rule, worship, morality, and the Prophet's guidance. As an Islamic-based educational institution, Al-Hikmah developed a learning model of the Realistic Circle Learning (RCL) model, an educational concept that emphasizes skills in socialization, independence, responsibility, communication, physical stabilization, and problem-solving. Students learn from curiosity, are trained to try to find answers and find knowledge independently, and communicate with others. To support the implementation of the RCL model, Al-Hikmah applies moving class learning by providing eight centers, namely: Centra preparation; the center of natural materials; Centra Balok; art center; centra Worship; center body exercise; Music center; and role-play centers. Each center is intended to develop children's competence.

Al-Hikmah more emphasized religious characters, which are derived from the teachings of Islam. The Qur'an and Sunnah become references in character education. Praying and reading the Qur'an is mandatory for all children. When they learn the prayer, it is like an adult, for men wearing long pants or sarongs and "Copiah", and women using "mukena".

As an educational institution based on Islam, the attitude and behavior of Prophet Muhammad SAW became a reference for character education. Rasulullah has truthful nature (sidiq), can be trusted (trust), intelligent (fathonah), and spread goodness (tabliqh). The method used to embed characters is habituation, stories, and exemplary from Rosul and friends. Many stories about Rosul and friends who can be role models. In addition to the story of Rosul, also stories about everyday life, and stories about animals become material in character education.

The habits carried out include that every day, the teacher welcomes the arrival of greeting children in front of the school by greeting, and the children kiss the hands of the teachers one by one. On the other hand, the teacher also embraces the students as a form of affection. This habit is intended to instill the value of respect for parents and love for children. To foster compassion, Al-Hikmah also has a "brother-sister program" by presenting elementary, middle, high school, and college students from universities under the Foundation in turns.

Discipline and compliance with regulations are taught in various ways, including when queuing, placing goods (shoes, bags) by the place. This discipline is also related to responsibility for himself, and respect for the rights of others. If there is a conflict between children, at the end of the lesson, it is thoroughly discussed using the problem-solving method and involves the students. This method is intended to give examples of character, what is right, and what is not good. 


\section{TK BTB}

Bina Tunas Bangsa Kindergarten (TK BTB) is not a school that based on religion has a vision as an educational institution to prepare a generation of noble people, have a strong personality, think critically, and are independent. While its mission is to lay a solid moral foundation, build an elegant figure, and develop critical thinking skills.

The characters emphasized in TK BTB are honesty, responsibility, independence, courtesy, and confidence. How to teach morality by seeing what the child conveys with what is done. For example, when a child asks for permission to go to the bathroom, is he going to the toilet or playing. If something is not appropriate, then the teacher tells us that the child must be honest. If you want to play, you also have to say to play, can't know you're going to the bathroom.

Responsibility is related to the ability to take care of their own and school property. After they play, it is considered whether they return the toys to their original places, as their teacher taught them. If it turns out there is a child who does not respond to his home, the teacher calls to be invited to return to its original place. The method used in character education in BTB Kindergarten is the habituation of children through exemplary teachers. Besides, habituation and excellent character education in TK BTB are carried out by inviting, giving examples, and asking questions. Inviting and giving examples are used to replace commanding actions. The teacher avoids the act of commanding the child so that later, the child can not only govern but will not do it himself. This is considered to lead to an authoritarian attitude towards children in the future.

Whereas by inviting or giving examples, it is hoped that children will imitate what their teachers do. Teachers must set a sample first, to teach good character. For example, the teacher gives an example to apologize to students if they make a mistake. The teacher also thanks the students who helped. While the questioning method is used to replace prohibiting actions, if there are children who do evil deeds, the teacher does not immediately forbid or scold but instead asks why the child does that. In this way, the teacher can find out the reason. Thus, the teacher can find out the cause and provide information if the ideas are incorrect.

Polite is taught directly to children when they talk. Among the manners taught are saying greeting friends with the right words. Likewise, when speaking to the teacher explained slowly, do not have to be in a hurry, or while running, if talking to the teacher must be quietly in place or sitting. Self-Confidence character was taught by participating in competitions both at the national and municipal levels. Children are encouraged to dare to appear in every race. According to the Head of TK BTB participation in the game, in addition to fostering selfconfidence, also intended to develop self-potential and creativity.

\section{TK Lab School}

Lab School Kindergarten is one of the early education assisted by Surabaya State University. TK Lab School has a vision to be a center of motivation and development of early childhood education that is in charge of noble character and Godhead in every movement of activities to achieve life skills based on the theory and practice of education in accordance with the development of children to produce human resources which is useful for the homeland, the nation and the motherland. One of the missions related to character is to guide children to have a positive conscience and virtuous character, and noble character. One of Labschool's kindergarten missions is to establish a noble character and generous character.

The characters that become a priority in TK Lab School are tolerance for differences, love one another, discipline, honesty, responsibility, please help. Tolerance was chosen as a priority character because this kindergarten has students with various backgrounds, both religious, 
socioeconomic, and intelligence. In this kindergarten, there are children with special needs. For children with special needs, children are taught to love and help. Tolerance of other religions is taught by introducing different religions of their friends. They were also introduced that each religion has a different way of worship. They also teach to play with friends of different faiths. Once a week, there is a moral lesson. Children are grouped according to their parents' trust and study with teachers of the same principle. In TK Lab School, there are four groups, namely Islam, Kristen, Catholic, and Hinduism.

Loving each other is related to friends, please help. For example, if there are friends who do not bring lunch, then those who bring lunch are taught to share. If there is a friend who falls must be helped. Discipline is associated with children's independence. One form of autonomy is that parents not accompany their children longer. Within two weeks, children no longer have to be accompanied by their parents. He must dare to enter the class alone. Honesty is associated with respecting the rights of others. For example, if you borrow a friend's item must be returned and or associated with responsibility. For example, whoever has taken a book, moved or dropped it must return it to its original place.

\section{Surabaya Gramer School (SGS)}

Surabaya Gramer School (SGS) kindergarten has a vision of being committed to educating students thoroughly, by building curiosity and enthusiasm for learning through an innovative and fun curriculum. While its mission is to shape the personality and potential of students to provide provisions for life in dealing with the environment and skills for future use. SGS is an elite and exclusive kindergarten because almost all of its students are ethnic Chinese. Although this kindergarten is not based on religion, nearly all of its students are Christians, Catholics or Buddhists. SGS learning using English. The curriculum used is also a combination of the national curriculum and the Singapore curriculum.

Nevertheless, character education is also a priority at SGS. Character education is carried out through a "moral education" program which is scheduled once a week. The characters emphasized are independent, disciplined, honest, social care, national spirit, and love to read. The methods used include storytelling, role-playing, coloring, making skills, community service, to doing regular social service activities.

They also have 11 pillars of characters that become a reference in daily learning, namely: (1) attitude; (2) caring; (3) determination; (4) fairness; (5) honesty; (6) integrity; (7) kindness; (8) politeness; (9) respect; (10) team spirit; and (11) understanding. Even though each kindergarten has a different character priority implanted, there are similarities in the characteristics of the four PAUD, which are honesty, independence, responsibility, and good manners. In learning activities, the characters are interrelated, meaning that in one action can be used to instill more than one role. For example, queuing events, in addition to teaching discipline, also teaches the attitude of honesty, compliance with regulations, and respect for the rights of others. The methods used to instill character are habituation, exemplary, singing, storytelling, slogans, and pat. Therefore, the role of the teacher in education in PAUD is enormous. The teacher is not only required to be an example, but also to be creative in making songs, stories, and slogans that contain characters. Yells that are combined with motion and pat are intended to provide character reinforcement and encourage the children. 


\section{The obstacles}

The obstacles faced by the four kindergartens in character education are habits that occur in the family environment. Often the words, attitudes, and behavior of parents at home are not in line with the character taught at school. This can be understood because the background level of education and social culture of parents is different. While the way of learning for children of kindergarten age is imitation (behaviorist), watching, understanding. Children often mimic words or actions taken by parents at home. What he saw, and heard at home was also imitated at school. Different habits at home between children in school often become a source of conflict between them. When the teacher asks the child, why do an action or say words that are considered impolite or right, the answer because their father or mother was also doing it too.

The parents were rarely this condition. They do not know that whatever is done (words, attitudes, and actions) will be imitated by children. Even though the child cannot speak, what he hears will be copied when he can talk. What is heard becomes a reference when he can speak. This is in line with the conditions; if the child is deaf from birth, he will also be unable to speak. Habits at home, which are not in line with what is taught at school, are a problem that must be addressed by teachers. Children get different knowledge about the same thing. What is taught at school is not always the same as what they experience at home. These differences can cause a dilemma in children, which one must follow. To overcome the child's dilemma, Al-Hikmah Kindergarten fosters collaboration with parents. By utilizing communication technology (HP), parents can monitor what children are doing at school. On the other hand, teachers can also report what children do at school. Vice versa, teachers can control what children do at home, and parents can also provide information to teachers what children do at home. Communication like this is done almost every day.

Communication between schools and parents is also carried out by TK Lab School, TK SGS, and TK BTB, although it is not as intensive as that of TK Al-Hikmah. At TK Lab School, there is a parenting program that is carried out in conjunction with student activities. In these activities, all parents are invited. The opportunity is used to educate parents with the method of dialogue or encourage resource persons. Education for parents is considered necessary because often, parents teach children to be intolerant. Communication with parents is also done directly if there are problems in children who are considered severe.

Teacher's character influence students' behavior. The child will also imitate the attitude, speech, and practice of the teacher's song. Even the teacher is often the primary model for children, compared to their parents. Although in one school, the personality and knowledge of teachers are also different. From the academic aspect, there is a requirement that PAUD teachers must be educated with a degree, but from the perspective of personality varies greatly. Teachers' attitudes and behavior toward children can change. Even the teacher's feelings will affect a child's perspective. Children have sensitive sense sensitivity. When the teacher is angry because of problems at home (e.g. fighting with her husband), the children also do not want to with the teacher. Kindergarten teachers must be able to manage emotions well because children need tenderness, affection, and sincerity. The ability to manage emotions is more necessary than knowledge.

Realizing the importance of personality, Al-Hikmah conducts rigorous selection in teacher acceptance. The choice is not only from the academic aspect but also from the personality aspect. The teachers at Al-Hikmah do not all have educational backgrounds. There are teachers with non-educational undergraduate backgrounds. The current head of Al-Hikmah Kindergarten is a psychology graduate. Teachers who have patience, affection, and sincerity take precedence over knowledge. In the SGS Kindergarten, teacher recruitment is also carried 
out rigorously selection, especially English language skills. Teachers must have excellent English skills because learning and daily conversation use English. In addition to language skills, teachers are also demanded to have good creativity and personality, accordance with 11 pillars of characters that are used as a reference for education.

Teacher recruitment selection is also made in TK BTB and Lab School, although not as rigorously as in AL Hikmah or SGS. This is influenced by the financial capacity of the institution. AL Hikmah is an educational foundation that has schools ranging from PAUD to universities. The cost of education at AL Hikmah is more expensive compared to TK BTB or Lab School. Teacher salaries in Al-Hikmah are higher than those in TK BTB or Lab School, so the quality of teachers, including sincerity in teaching, is also better. Likewise, the salary of teachers in SGS Kindergarten has fulfilled teacher payroll standards. They receive a wage above the Surabaya regional minimum wage.

The economic background, education, and social status of parents of children in AlHikmah and SGS are also higher than those in BTB and Lab School. This condition has an impact on awareness of the importance of education to be higher, so that collaboration between schools and parents is easier to do. The economic, educational, and social status of children's parents at BTB can be said to be the lowest compared to at Lab School or AlHikmah or SGS, so the character learning process often clashes with the habits of children at home. Parental support and commitment to children's education are also not as strong as in Lab School or Al-Hikmah, or SGS. Character education which is considered the most difficult of the three kindergartens (Al-Hikmah, Lab School, and BTB) is instilling honesty. Children are honest, but parents or people indirectly taught dishonestly. As a result, children begin to learn by imitating dishonesty that occurs in the family or the surrounding community.

\section{Conclusion}

Character education in Surabaya City Kindergarten uses the same reference, which is the 2013 curriculum. However, there are differences in the character's priorities, according to their respective vision and mission. Although schools do education, the children's attitude is also influenced by the teacher, family environment, and society. The family circle is the first educational institution that teaches children character. Words, beliefs, and behavior of parents will be a reference character of the child. Likewise, the words, attitudes, and practices of teachers in schools will be imitated by children. Therefore, the collaboration between schools and parents is needed in character education. Schools and parents need to agree on what kind of character is instilled in children.

Among the characters that are important to instill in the kindergarten are honesty, tolerance, independence, responsibility, discipline, creativity, courtesy, and social concern. These characters can be empirically exemplified and accustomed to in everyday life. The essential character foundation is honesty, and at the same time, can be social capital. Tolerance and social care are the characters that underlie national unity and integrity. Creativity, independence and responsibility, and discipline will be the capital to become productive people. While manners are part of excellent love communication and respect for others.

The method of character education for children is habituation and example. Therefore, teachers and parents must be aware that they become models for children. This example can also be through stories about characters who have the characteristics as expected. The 
approach used in character education in children is love and sincerity because children are susceptible and sensitive to the attitudes and behavior of teachers. Therefore, kindergarten teachers must have compassion for children and are sincere in working. Besides, teachers must also be creative in learning because children get bored quickly and cannot hold prolonged concentrations.

\section{References}

[1] A. Pala, "The Need for Character Education," Int. J. Soc. Sci. Humanit. Stud., vol. 3, no. 2, pp. 32-39, 2011.

[2] H. Widyaningsih, "Model Pendidikan Karakter Pada Anak Usia Dini melalui Program Islamic Habituation.," J. Indig., vol. 1, no. 2, pp. 22-31, 2016.

[3] T. Lickona, Educating for Character Mendidik Untuk membentuk Karakter. Jakarta: Bumi Aksara, 2012.

[4] L. T. Crandell, Human Development. New York: McGraw-Hill, 2009.

[5] Warsono, Pancasila-isme Dalam Dinamika Pendidikan, 2nd ed. Surabaya: Unesa University Press., 2016.

[6] A. Rosenberg, Philosophy of Social Science. Philadelphia: Australia West view Press., 2008.

[7] S. Duchesne, Educational Psychology. Australia: National Library of Australia., 2016.

[8] P. D. Johnson, Contemporary Sociological Theory, An Integrated Multi-Level Approach. Texas Tech University: Springer., 2008.

[9] H. D. Schunk, Learning Theories an Educational Perspective. New Jersey: Pearson., 2004.

[10] W. J. Santrock, Educational Psychology. New York: McGraw-Hill, 2009. 